\title{
PERAN KUALITAS PRODUK, HARGA DAN KUALITAS LAYANAN TERHADAP KEPUASAN PELANGGAN BILLAGIO SKINCARE CLINIC SIDOARJO
}

\author{
Ana Fitriyatul Bilgies \\ Fakultas Ekonomi, Universitas Darul 'Ulum - Lamongan E- \\ mail:anabilgies@yahoo.com
}

\begin{abstract}
Abstrak
Bisnis di bidang perawatan kecantikan dewasa ini telah berkembang pesat seiring dengan kemajuan jaman di indonesia, salah satu perusahaan tersebut adalah Billagio Skincare Clinic Sidoarjo. Namun seiring kemajuan tersebut terjadi fenomena penurunan pendapatan dan meningkatnya komplain pelanggan. Penelitian ini bertujuan untuk mengetahui pengaruh kualitas produk, harga dan kualitas layanan terhadap kepuasan pelanggan Billagio skincare clinic Sidoarjo. Dalam penelitian ini menggunakan variabel kualitas produk, harga dan kualitas layanan, sedangkan responden penelitian adalah seluruh pelanggan Billagio Skincare Clinic Sidoarjo dengan metode accicental sampling dan teknik analisis serta pengujian hipotesis menggunakan software Partial Least Square (PLS). Hasil pengujian menunjukkan bahwa kualitas produk yang baik menimbulkan kepuasan yang tinggi pada pelanggan, namun harga tidak berpengaruh pada kepuasan pelanggan, sedangkan kualitas pelayanan yang baik berdampak pada pelanggan semakin puas.
\end{abstract}

Kata Kunci : Kualitas produk, harga, kualitas layanan, kepuasan pelanggan

\section{PENDAHULUAN}

\section{Latar Belakang}

Puas atau tidaknya konsumen adalah respon terhadap evolusi ketidaksesuaian yang dirasakan antara harapan sebelumnya dan kinerja aktual produk yang dirasakan bahwa pada persaingan yang semakin ketat ini, semakin banyak produsen yang terlibat dalam pemenuhan dan keinginan konsumen sehingga hal ini menyebabkan setiap badan usaha harus menempatkan orientasi pada kepuasan konsumen sebagai tujuan utama, antara lain dengan semakin banyaknya badan usaha yang menyatakan komitmen terhadap kepuasan konsumen dalam pernyataan misi, (Musanto, $2004: 125$ ).

Produk adalah segala sesuatu yang dapat ditawarkan oleh produsen untuk diperhatikan, diminta, dicari, dibeli, disewa, digunakan atau di konsumsi pasar (baik pasar konsumen akhir maupun pasar industrial) sebagai pemenuhan kebutuhan atau keinginan pasar yang bersangkutan. (Tjiptono 2002:22). Kualitas produk adalah faktor penentu kepuasan konsumen setelah melakukan pembelian dan pemakaian terhadap suatu produk. Dengan 
kualitas produk yang baik maka keinginan dan kebutuhan konsumen terhadap suatu produk akan terpenuhi. Menurut Handoko (2002 : 23) kualitas produk adalah suatu kondisi dari sebuah barang berdasarkan pada penilaian atas kesesuaiannya dengan standar ukur yang telah ditetapkan.

Dengan adanya kualitas produk dan kualitas pelayanan yang baik dan didukung dengan strategi penetapan harga yang mampu bersaing (kompetitif) tentunya juga akan mempengaruhi rasa kepercayaan konsumen. Saat ini dengan berbagai pelayanan yang bersaing, Sementara itu sudah ada produk Kecantikan dan lain sebagainya. Dengan memahami faktor-faktor yang menjadi pertimbangan pelanggan dalam membeli produk tersebut, maka diharapkan Bellagio skin care clinic dapat mempengarui dan mempertahankan pelanggannya, sehingga Bellagiio skin care clinic dapat terus melaksanakan diantara situasi krisis dan persaingan usaha.

\section{Rumusan Masalah}

1. Apakah Kualitas Produk berpengaruh terhadap kepuasan pelanggan di Bellagio skin care clinic Sidoarjo?

2. Apakah Harga berpengaruh terhadap kepuasan pelanggan di Bellagio skin care clinic Sidoarjo ?

3. Apakah Kualitas Layanan berpengaruh terhadap kepuasan pelanggan di Bellagio skin care clinic Sidoarjo?

\section{Tujuan Penelitian}

1. Untuk mengetahui pengetahui kualitas produk terhadap kepuasan pelanggan di Bellagio skin care clinic Sidoarjo?

2. Untuk mengetahui pengaruh harga terhadap kepuasan pelanggan di Bellagio skin care clinic Sidoarjo ?

3. Untuk mengetahui penggaruh kualitas layanan terhadap kepuasan pelanggan di Bellagio skin care clinic Sidoarjo?

\section{TINJAUAN PUSTAKA}

\section{Pengertian Kepuasan Pelanggan}

Kepuasan pelanggan sebagai sikap keseluruhan terhadap suatu barang atau jasa setelah perolehan dan pemakaiannya. Tjiptono (2000 : 90) Menurut Samuel (2005 : 76) bahwa kepuasan Pelanggan dibentuk oleh 3 indikator, antara lain: 1) Kepuasan pada kualitas produk, 2) Kepuasan pada harga produk 3) Kepuasan pada pelayanan yang diberikan karyawan. Dalam Penelitian Ardhanari (2008) kepuasan pelanggan dibentuk dari tiga atribut, antara lain:

- Attributes related to the product, yaitu kepuasan yang disebabkan oleh atribut yang berhubungan dengan produk.

- Attributes related to service yaitu kepuasan yang disebabkan oleh atribut yang berhubungan dengan layanan / jasa. 
- Attributes related to purchase yaitu kepuasan yang disebabkan oleh atribut pada saat proses pembelian.

\section{Pengertian Kualitas Produk}

Produk adalah sesuatu yang ditawarkan kepada pasar untuk mendapatkkan perhatian, untuk dimiliki, digunakan, ataupun dikonsumsi untuk memenuhi suatu kebutuhan atau keinginan. Kualitas produk merupakan kemampuan dari suatu produk dalam menjalankan fungsinya. Kualitas produk mempunyai hubungan yang sangat erat dengan kepuasan pelanggan karena kualitas produk dapat dinilai dari kemampuan produk tersebut untuk menciptakan kepuasan pelanggan. Chase \& Aguilano dalam Pramita (2010), berpendapat bahwa kualitas dari suatu produk ditentukan oleh pelanggan melalui karakteristik yang ada pada suatu produk dan jasa, dimana puas dan tidaknya pelanggan dipengaruhi oleh nilai yang didapat dengan mengkonsumsi suatu produk. Semakin tinggi tingkat kualitas produk dalam memuaskan pelanggan, maka akan menyebabkan kepuasaan pelanggan yang tinggi pula (Kotler dan Amstrong, 2008). Mowen, dkk (2002) berpendapat kualitas produk mempunyai pengaruh yang bersifat langsung terhadap kepuasan pelanggan. Dengan meningkatkan kemampuan suatu produk, akan tercipta keunggulan bersaing sehingga pelanggan menjadi semakin puas.

Kualitas produk menggambarkan sejauh mana kemampuan produktersebut dalam memenuhi kebutuhan pelanggan. Definisi dari kualitas produk mencerminkan kemampuan produk untuk menjalankan tugasnya yang mencakup daya tahan, kehandalan atau kemajuan, kekuatan, kemudahan dalam pengemasandan reparasi produk dan ciri- ciri lainnya Kotler dan Amstrong (2004). Kualitas produk dibentuk oleh indicator antara lain (marhayani dan sihite, 2008 ) : 1) Kemampuan produk, 2) Keistimewaan produk, 3) Daya tahan produk

\section{Pengertian Harga}

Harga dalam penelitian ini adalah salah satu variabel yang dianggap mempengaruhi keputusan pembelian konsumen. Menurut E.Jerome McCarthy dan William D. Perrefault,Jr (1993:351), harga merupakan salah satu variabel yang dikendalikan manajer pemasaran. Keputusan tingkat harga sangat penting karena mempengaruhi jumlah penjualan yang dapat dicapai perusahaan dan uang yang diperolehnya. Harga adalah segala sesuatu atau nilai yang ditetapkan bagi "sesuatu".

Dalam arti yang paling sempit, harga adalah jumlah uang yang dibebankan atas suatu produk atau jasa. Lebih luas lagi, harga adalah jumlah dari seluruh nilai yang ditukar konsumen atas manfaat memiliki atau menggunakan produk atau jasa tersebut. (Kotler dan Amstrong, 2001:439). Dalam proses penetapan harga sebaiknya dilakukan sesuai dengan tujuan perusahaan dan pemasaran. Penetapan harga dilakukan perusahaan berdasarkan banyak pertimbangan. Menurut Stanton (2003), harga tidak lain hanyalah sebuah eksperimen untuk menguji denyut nadi pasar. Jika pelanggan menerima tawaran berarti harga tersebut sudah tepat. Jika mereka menolak biasanya harga akan cepat diganti atau bila perlu produk bisa ditarik dari peredarannya.Ada 4 (tempat) Indikator yang mencirikan harga yaitu, (Stanton, 1998) : 1) Keterjangkauan harga, Kesesuaian harga dengan kualitas produk, 3) Kesesuaian harga dengan manfaat. 4) Daya saing harga. 


\section{Pengertian Kualitas Layanan}

Mutu merupakan istilah yang mempunyai makna yang berbeda bagi setiap orang. Memahami dimensi mutu produk perusahaan merupakanlangkahawal dalam mengembangkan dan memelihara keunggulan produk dalam persaingan bisnis. Ada beberapa pakar pemasaran telah mengimbangkan dimensi kualitas jasa atau sering disebut sebagai faktor utama yang mempengaruhi atau menentukan kualitas jasa berdasarkan pengalaman dan penelitiannya terhadap beberapa perusahaan baik manufaktur maupun jasa. Parasuraman et. Al, $2000: 44$ ) mengemukakan 5 dimensi kualitas layanan (X2) yang terdiri dari :

1. Bukti fisik (tangible) adalah penampilan dari fasilitas-fasilitas fisik, perlengkapan individu dan alat-alat komunikasi.

2. Keandalan (reliabilty) adalah kemampuan karyawan untuk memberikan layanan yang dapat diandalkan dan akurat.

3. Daya tanggap (responsiveness) adalah kesediaan untuk membantu dan memberikan layanan yang tepat bagi pelanggan.

4. Jaminan (assurance) adalah dimensi kualitas layanan yang memfokuskan pada kemampuan untuk mendapatkan kepercayaan dan keyakinan pelanggan.

5. Empati (Empathy) adalah memberikan perhatikan yang tulus dan bersifat individual atau pribaddi kepada pelanggan dengan berupaya memahami keinginan pelanggan.

\section{Pengaruh Kualitas Produk Terhadap Kepuasan Pelanggan}

Produk didefinisikan sebagai sesuatu yang dapat ditawarkan kedalam pasar untuk diperhatikan, dimiliki, dipakai, atau dikonsumsi sehingga dapat memuaskan kebutuhan atau keinginan. Produk yang berkualitas adalah produk yang mampu memberi manfaat yang lebih dari yang diharapkan. Apabila diutarakan lebih rinci kualitas memiliki dua prspektif yaitu perspektif produsen \& pelanggan, dimana bila kedua hal itu digabungkan maka yang akan dapat tercapai kesesuaian yang dapat digunakan pelanggan.

Dalam dunia usaha, istilah kualitas sangat penting bagi perusahaan, karena; reputasi perusahaan, penurunan biaya, peningkatan pangsa pasar, dan penampilan produk.suatu produk dikatakan berkualitas bila mempunyai nilai subyektifitas yang tinggi antara pelanggan yang satu dengan pelanggan yang lain. Naser, at all (dalam Hadi; 2002) mengatakan bahwa kepuasan pelanggan sangat tergantung pada bagaimana tingkat kualitas produk yang ditawarkan. Hasil penelitian Anderson dan Lindestad membuktikan bahwa kualitas produk (diukur dari persepsi pelanggan atas tingkat kerusakan produk) mempengaruhi tingkat kepuasan pelanggan. Kepuasan pelanggan mengindikasikan adanya kesetiaan pelanggan terhadap produk, serta dapat mengurangi elastisitas harga, mencegah pelanggan direbut pesaing, biaya transaksi mendatang lebih murah, mengurangi biaya kegagalan, dan dapat meningkatakan reputasi perusahaan.

Berdasarkan hasil penelitian yang dilakukan oleh V. Mital, WT. Ross dan PM. Baldasare (1998) mengemukakan bahwa kinerja yang negatif pada produk atribut mempunyai efek negatif pada kepuasan keseluruhan dan kinerja yang positif pada produk mempunyai pengaruh positif pada atribut yang sama dan kepuasan keseluruhan menunjukkan pengurangan sensitivitas pada tingkat kinerja atribut dalam Jurnal Mulyono, Dkk. (2003). Berdasarkan 
pendapat diatas, peneliti menyimpulkan kualitas produk yang meningkat menunjukkan kepuasan pelanggan yang juga meningkat.

\section{Pengaruh Harga Terhadap Kepuasan Pelanggan}

Harga adalah sejumlah uang yang dibebankan atas suatu produk atau jasa, atau jumlah dari nilai yang ditukar pelanggan atas manfaat-manfaat karena memiliki atau menggunakan produk atau jasa tersebut. ( Kotler dan Amstrong : 2001 ).

Dalam membeli suatu produk pelanggan tidak hanya mempertimbangkan kualitasnya saja, tetapi juga memikirkan kelayakan harganya (Sweeney,et.al,2001). Harga merupakan salah satu penentu pemilihan produk yang nantinya akan berpengaruh terhadap kepuasan. Harga seringkali dikaitkan dengan kualitas, pelanggan cenderung untuk menggunakan harga sebagai indikator kualitas atau kepuasan potensial dari suatu produk. Bila suatu produk mengharuskan pelanggan mengeluarkan biaya yang lebih besar dibandingkan dengan manfaat yang diterima, maka yang terjadi adalah produk tersebut memiliki nilai negatif. Sebaliknya, apabila pelanggan mengganggap bahwa manfaat yang diterima lebih besar, maka yang terjadi adalah produk tersebut memiliki nilai yang positif. Para pelanggan tertarik untuk mendapatkan harga yang pantas. Harga yang pantas berarti nilai yang di persepsikan pantas pada saat transaksi dilakukan. Pelanggan beranggapan bahwa suatu produk dengan harga yang mahal berarti mempunyai kualitas yang baik.

Harga merupakan variabel yang dapat dikendalikan dan menentukan diterima atau tidaknya suatu produk oleh pelanggan. Harga semata-mata tergantung pada kebijakan perusahaan, tetapi tentu saja dengan mempertimbangkan beberapa hal. Murah atau mahalnya harga suatu produk sangat relative sifatnya. Untuk mengatakannya perlu terlebih dahulu dibandingkan dengan harga produk serupa yang di produksi atau dijual perusahaan lain. Perusahaan perlu memonitor harga yang ditetapkan oleh para pesaing agar harga yang ditentukan oleh perusahaan tidak terlalu tinggi atau sebaliknya, sehingga harga yang ditawarkan apabila sesuai dengan apa yang diharapkan pelanggan akan dapat menimbulkan kepuasan pelanggan. Hasil penelitian Arlina Nurbaity dan Martin (2009) menyatakan bahwa harga berpengaruh positip terhadap kepuasan pelanggan. Harga akan mempengaruhi kepuasan pelanggan apabila harga suatu produk sesuai dengan kualitas, terjangkau, dan sesuai dengan manfaat yang diterima menimbulkan kepuasan pada pelanggan.

Banyak hal yang berkaitan dengan harga yang melatarbelakangi mengapa pelanggan memilih suatu produk untuk dimilikinya. Pelanggan memilih suatu produk tersebut karena benar-benar ingin merasakan nilai dan manfaat dari produk tersebut, karena melihat kesempatan memiliki produk tersebut dengan harga yang lebih murah dari biasanya sehingga lebih ekonomis, kerena ada kesempatan untuk mendapatkan hadiah dari pembelian produk tersebut, atau karena ingin dianggap pelanggan lain bahwa tahu banyak tentang produk tersebut dan ingin dianggap loyal.

Harga dilihat dari sudut pandang pelanggan, seringkali digunakan sebagai Indikator nilai bilamana harga tersebut dihubungkan dengan manfaat yamg dirasakan atas suatu barang atau jasa. Kertajaya (2002) mengungkapkan bahwa indikator penilaian harga dapat dilihat dari kesesuaian antara suatu pengorbanan dari pelanggan terhadap nilai yang diterimanya setelah melakukan pembelian, dan dari situlah pelanggan akan mempersepsi dari produk atau jasa tersebut. Jika harga yang ditetapkan oleh sebuah perusahaan tidak sesuai dengan 
manfaat produk maka hal itu dapat menurunkan tingkat kepuasan pelanggan, dan sebaliknya jika harga yang ditetapkan oleh sebuah perusahaan sesuai dengan manfaat yang diterima maka akan meningkatkan kepuasan pelanggan. Dengan demikian dapat disimpulkan bahwa pada tingkat harga tertentu, jika manfaat yang dirasakan meningkat, maka nilainya akan meningkat pula. Apabila nilai yang dirasakan pelanggan semakin tinggi, maka akan menciptakan kepuasan pelanggan yang maksimal (Tjiptono, 2001).

\section{Pengaruh Kualitas Layanan Terhadap Kepuasan Pelanggan}

Kualitas layanan adalah suatu bentuk penilaian pelanggan terhadap tingkat layanan yang diterima dengan tingkat yang diharapkan (Lupiyadi, 2001:81). Sedangkan Parasuraman (2000 : 44) mendefinisikan kualitas layanan sebagai persepsi pelanggan atas jasa yagn mereka terima. Pada umumnya harapan palanggan merupakan perkiraan atau keyakinan pelanggan tentang apa yang akan diterimanya apabila ia membeli atau mengkonsumsi suatu produk baik barang maupun jasa, sedangkan kinerja atau hasil yang dirasakan merupakan persepsi pelanggan terhadap apa yang ia terima setelah mengkonsumsi produk yang ia beli.

Kualitas pelayanan merupakan evaluasi pelanggan tentang kesempurnaan kinerja layanan. kualitas pelayanan mempunyai pengaruh positif terhadap kepuasan pelanggan. Jadi dengan peningkatan kualitas layanan yang diberikan kepada pelanggan maka kepuasan pelanggan akan tercipta. Berdasarkan hasil penelitian yang dilakukan oleh Kartika Sukmawati (2011) mengemukakan bahwa terdapat pengaruh positif antara kualitas pelayanan terhadap kepuasan Pelanggan. Hal ini berarti bahwa kualitas pelayanan pelanggan jasa Transportasi Kereta Api Eksekutif memiliki pengaruh yang signifikan terhadap kepuasan pelanggannya. Berdasarkan pendapat diatas, maka peneliti menyimpulkan kualitas layanan yang meningkatakan menunjukkan kepuasan pelanggan yang juga meningkat.

\section{Gambar 1. Kerangka Konsep}

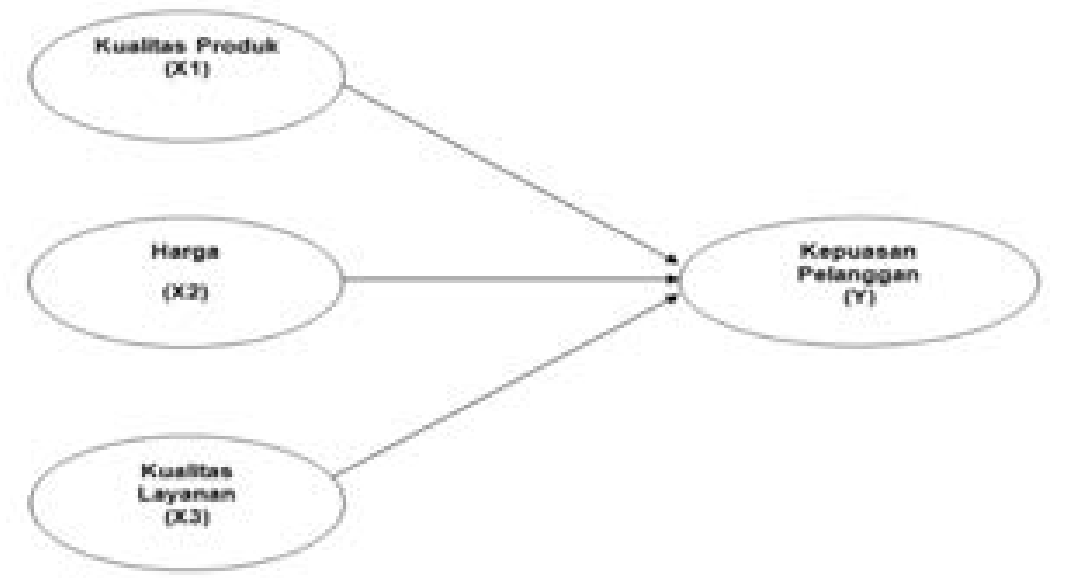

\section{Hipotesis Penelitian}

1. Semakin baik kualitas produk maka semakin puas pelanggan

2. Semakin sesuai Harga maka semakin puas pelanggan

3. Semakin baik Kualitas layanan maka semakin puas pelanggan 


\section{METODE PENELITIAN}

Skala pengukuran dalam penelitian ini adalah skala Interval dengan mengggunakan metode Skala Likert dengan skor 1 sampai dengan 5 pernyataan persetujuan. Sedangkan Populasi dalam penelitian ini adalah pelanggan yang membeli produk dan menggunakan jasa perawatan pada Billagio skincare clinic Sidoarjo dan teknik pengambilan sampel menggunakan metode accidental sampling sebanyak 50 responden. Dan alat analisis yang dipergunakan adalah Partial Least Square (PLS).

\section{HASIL PENELITIAN.}

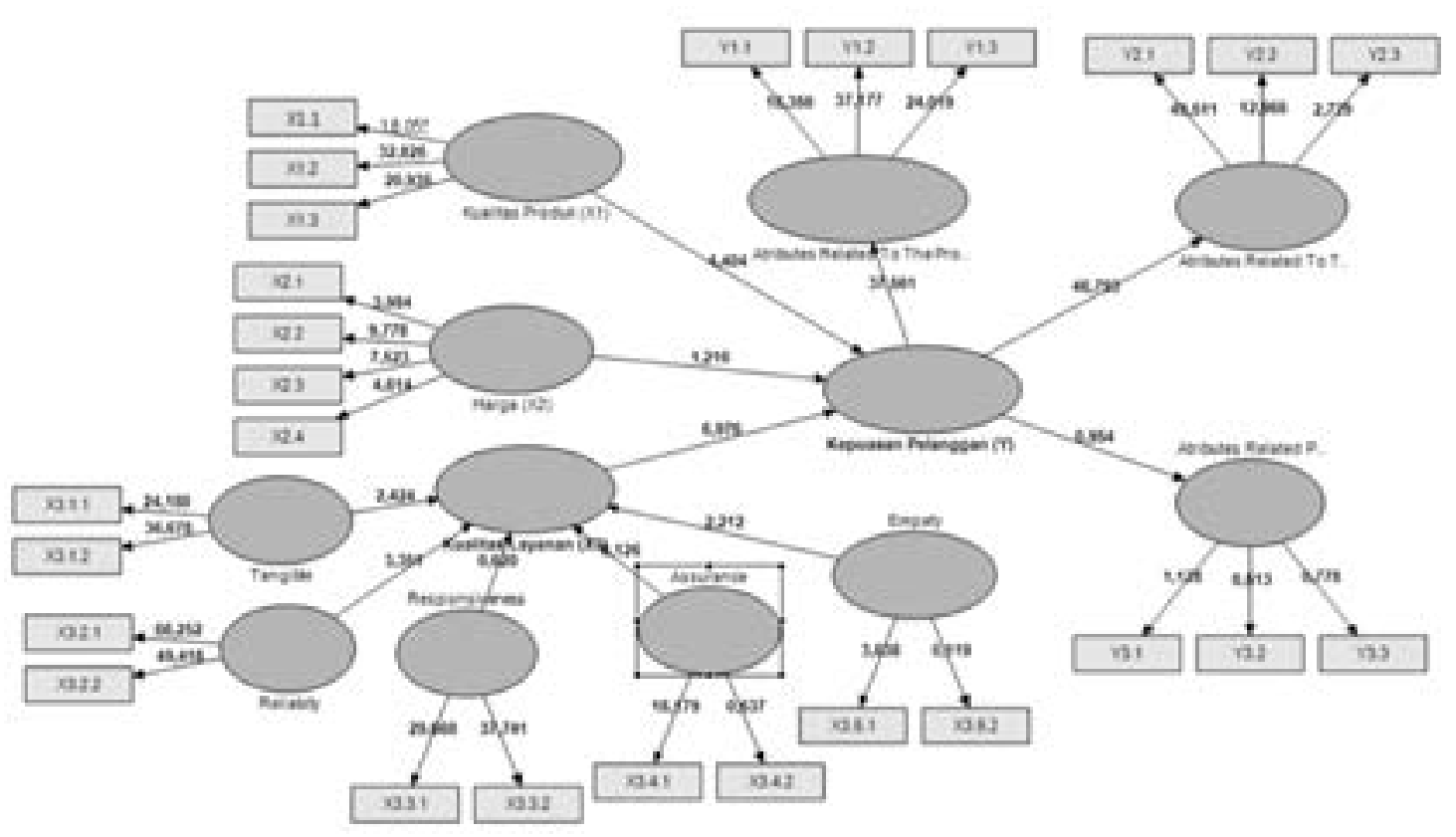

Tabel Outer Loadings (Mean, STDEV, T-Values)

\begin{tabular}{|c|c|c|c|c|c|}
\hline & $\begin{array}{l}\text { Factor } \\
\text { Loading (0) }\end{array}$ & $\begin{array}{l}\text { Sample Mean } \\
\text { (M) }\end{array}$ & $\begin{array}{l}\text { Standard } \\
\text { Deviation } \\
\text { (STDEV) }\end{array}$ & $\begin{array}{l}\text { Standard Error } \\
\text { (STERR) }\end{array}$ & $\begin{array}{l}\text { T Statistics (|O } \\
\text { STERR|) }\end{array}$ \\
\hline X1.1 <- Kualitas Produk (X1) & 0,818240 & 0,820840 & 0,045319 & 0,045319 & 18,054920 \\
\hline X1.2 <- Kualitas Produk (X1) & 0,855612 & 0,853548 & 0,026065 & 0,026065 & 32,825801 \\
\hline X1.3 <- Kualitas Produk (X1) & 0,840062 & 0,842502 & 0,040128 & 0,040128 & 20,934530 \\
\hline X2.1 <- Harga (X2) & 0,546162 & 0,541578 & 0,137096 & 0,137096 & 3,983795 \\
\hline$X 2.2<-$ Harga $(X 2)$ & 0,826786 & 0,817492 & 0,084558 & 0,084558 & 9,777773 \\
\hline X2.3 <- Harga $(X 2)$ & 0,763492 & 0,747516 & 0,101489 & 0,101489 & 7,522870 \\
\hline$X 2.4<-\operatorname{Harga}(X 2)$ & 0,684255 & 0,645566 & 0,148306 & 0,148306 & 4,613813 \\
\hline
\end{tabular}

Sumber : Olah Data.

Validitas Indikator : Nilai Factor Loading lebih besar dari 0,5 dan atau nilai T-Statistic lebih besar dari 1,645 (nilai $\mathrm{Z}$ pada $\alpha=0,10$ ). Factor Loading merupakan korelasi antara indikator dengan variabel, jika lebih besar dari 0,5 maka korelasi disebut valid dan jika nilai TStatistic lebih besar dari 1,645 maka korelasinya disebut signifikan. Berdasarkan pada tabel outer loading di atas, pada indikator Kualitas Produk memiliki factor loading lebih 
besar dari 0,50 dan atau signifikan (Nilai T-Statistic lebih besar dari nilai $\mathrm{Z} \alpha=0,10 \quad(10 \%)$ = 1,645), tersebut adalah menjadi pengukur/indikator variabelnya. Secara keseluruhan hasil estimasi telah memenuhi Convergen vailidity dan validitas baik.

Pada indikator Harga menunjukkan seluruh indikator memiliki factor loading lebih besar dari 0,50 dan atau signifikan (Nilai T-Statistic lebih besar dari nilai $\mathrm{Z} \alpha=0,10(10 \%)=$ 1,645) ), tersebut adalah menjadi pengukur/indikator variabelnya. Secara keseluruahn hasil estimasi telah memenuhi Convergen vailidity dan validitas baik Secara keseluruahn hasil estimasi telah memenuhi Convergen vailidity dan validitas baik. Sedang model pengukuran indikator formatif yaitu Kualitas Layanan dan Kepuasan Pelanggan, maka cara menilainya adalah dengan melihat nilai koefisien regresi dan signifikansi dari koefisien regresi tersebut. Jadi dilihat nilai outer weight masing-masing indikator dan nilai signifikansinya.

Tabel Outer Weights (Mean, STDEV, T-Values)

\begin{tabular}{|c|c|c|c|c|c|}
\hline & $\begin{array}{l}\text { Factor } \\
\text { Loading (0) }\end{array}$ & $\begin{array}{l}\text { Sample Mean } \\
\text { (M) }\end{array}$ & $\begin{array}{l}\text { Standard } \\
\text { Deviation } \\
\text { (STDEV) }\end{array}$ & $\begin{array}{l}\text { Standard } \\
\text { Error } \\
\text { (STERR) }\end{array}$ & $\begin{array}{l}\text { T Statistics }(\mid \mathrm{O} / \\
\text { STERR } \mid)\end{array}$ \\
\hline X3.1.1 >> Kualitas Layanan (X3) & 0,158585 & 0,182814 & 0,134625 & 0,134625 & 1,177979 \\
\hline X3.1.2 > Kualitas Layanan (X3) & 0,318387 & 0,329184 & 0,086899 & 0,086899 & 3,663856 \\
\hline X3.2.1 > Kualitas Layanan (X3) & 0,338882 & 0,307736 & 0,101040 & 0,101040 & 3,353958 \\
\hline X3.2.2 -> Kualitas Layanan (X3) & 0,218814 & 0,192176 & 0,096723 & 0,096723 & 2,262269 \\
\hline X3.3.1 > Kualitas Layanan (X3) & $-0,021867$ & $-0,023914$ & 0,086943 & 0,086943 & 0,251512 \\
\hline X3.3.2 -> Kualitas Layanan (X3) & 0,110914 & 0,101082 & 0,084946 & 0,084946 & 1,305692 \\
\hline X3.4.1 -> Kualitas Layanan (X3) & $-0,017072$ & $-0,004647$ & 0,116025 & 0,116025 & 0,147139 \\
\hline X3.4.2 -> Kualitas Layanan (X3) & $-0,014419$ & $-0,026013$ & 0,059432 & 0,059432 & 0,242610 \\
\hline X3.5.1 -> Kualitas Layanan (X3) & 0,251769 & 0,221478 & 0,091539 & 0,091539 & 2,750396 \\
\hline X3.5.2 -> Kualitas Layanan (X3) & $-0,080658$ & $-0,088665$ & 0,070068 & 0,070068 & 1,151141 \\
\hline Y1.1 -> Kepuasan Pelanggan (Y) & 0,132755 & 0,127771 & 0,035437 & 0,035437 & 3,746193 \\
\hline Y1.2 -> Kepuasan Pelanggan (Y) & 0,282168 & 0,271929 & 0,044054 & 0,044054 & 6,405104 \\
\hline Y1.3 -> Kepuasan Pelanggan (Y) & 0,182908 & 0,179829 & 0,042545 & 0,042545 & 4,299157 \\
\hline Y2.1 -> Kepuasan Pelanggan (Y) & 0,379022 & 0,363706 & 0,047077 & 0,047077 & 8,051159 \\
\hline Y2.2 -> Kepuasan Pelanggan (Y) & 0,273979 & 0,269275 & 0,037911 & 0,037911 & 7,226876 \\
\hline Y2.3 -> Kepuasan Pelanggan (Y) & 0,004838 & 0,001310 & 0,064984 & 0,064984 & 0,074452 \\
\hline Y3.1 -> Kepuasan Pelanggan (Y) & 0,125915 & 0,069014 & 0,067628 & 0,067628 & 1,861880 \\
\hline Y3.2 -> Kepuasan Pelanggan (Y) & 0,015423 & 0,023078 & 0,053034 & 0,053034 & 0,290809 \\
\hline Y3.3 -> Kepuasan Pelanggan (Y) & $-0,014607$ & $-0,032800$ & 0,072610 & 0,072610 & 0,201165 \\
\hline
\end{tabular}

\section{result for inner weight}

Tabel path of coefficients (Mean, STDEV, T-Values)

\begin{tabular}{|l|l|l|l|l|l|}
\hline & $\begin{array}{l}\text { Original } \\
\text { Sample (O) }\end{array}$ & $\begin{array}{l}\text { Sample } \\
\text { Mean (M) }\end{array}$ & $\begin{array}{l}\text { Standard } \\
\text { Deviation } \\
\text { (STDEV) }\end{array}$ & $\begin{array}{l}\text { Standard Error } \\
\text { (STERR) }\end{array}$ & $\begin{array}{l}\text { T Statistics }(\mid \mathrm{O} / \\
\text { STERR })\end{array}$ \\
\hline $\begin{array}{l}\text { Kualitas Produk (X1) -> Kepuasan } \\
\text { Pelanggan (Y) }\end{array}$ & 0,313941 & 0,307511 & 0,071285 & 0,071285 & 4,404009 \\
\hline $\begin{array}{l}\text { Harga (X2) -> Kepuasan Pelanggan } \\
(\mathrm{Y})\end{array}$ & 0,098784 & 0,101998 & 0,081267 & 0,081267 & 1,215545 \\
\hline $\begin{array}{l}\text { Kualitas Layanan (X3) -> Kepuasan } \\
\text { Pelanggan (Y) }\end{array}$ & 0,531718 & 0,554198 & 0,076223 & 0,076223 & 6,975823 \\
\hline
\end{tabular}

Sumber : Olah Data. 
1. Kualitas produk (X1) berpengaruh terhadap Kepuasan Pelanggan (Y) dengan koefisien path sebesar 0,3139 dapat diterima dimana nilai T-Statistic $=4,4040$ lebih besar dari nilai $\mathrm{Z} \alpha=$ $0,10(10 \%)=1,645$, maka Signifikan (Positif)

2. Harga (X2) berpengaruh terhadap Kepuasan Pelanggan (Y) dengan koefisien path sebesar 0,0987, tidak dapat diterima dimana nilai $\mathrm{T}$-Statistic $=1,2155$ lebih kecil dari nilai $\mathrm{Z} \alpha=$ $0,10(10 \%)=1,645$, maka Non Signifikan (Positif)

3. Kualitas Layanan (X3) berpengaruh terhadap Kepuasan Pelanggan (Y) dengan koefisien path sebesar 0,5317 dapat diterima dimana nilai T-Statistic $=6,975$ lebih besar dari nilai $\mathrm{Z} \alpha=$ $0,10(10 \%)=1,645$, maka Signifikan (Positif) tidak menunjukan pengaruh keterjangkauan harga, kesuaian harga dengan kualitas produk maupun kesesuaian harga dengan manfaat terhadap Kepuasan Pelanggan.

\section{HASIL DAN PEMBAHASAN}

\section{Pengaruh Kualitas Produk Terhadap Kepuasan Pelanggan}

Dari hasil analisis diperoleh nilai validitas terbesar diantara tiga indikator yang ada adalah indikator X1.2 yaitu "Keistimewaan Produk" dengan nilai factor loading sebesar 0,855612, artinya indikator keistimewaan produk menjadi faktor utama bagi pelanggan menilai satu kualitas produk Billagio Skin Care. Hasil penelitian sebelumnya yang menyatakan bahwa adanya pengaruh kualitas produk terhadap kepuasan pelanggan terbukti kebenarannya dan sesuai dengan teori yang mengatakan bahwa kepuasan pelanggan sangat tergantung pada bagaimana tingkat kualitas produk yang ditawarkan (Naser, at all 2002) dan memperkuat teori suatu produk dapat memuaskan pelanggan bila dinilai dapat memenuhi atau melebihi keinginan \& harapannya (Spreng et.Al:1996).

Hal ini juga memperkuat hasil penelitian yang dilakukan oleh V. Mital, WT. Ross dan PM. Baldasare (1998) mengemukakan bahwa kinerja yang negatif pada produk atribut mempunyai efek negatif pada kepuasan keseluruhan dan kinerja yang positif pada produk mempunyai pengaruh positif pada atribut yang sama dan kepuasan keseluruhan menunjukkan pengurangan sensitivitas pada tingkat kinerja atribut. Dalam Jurnal Mulyono, Dkk. (2003), artinya kepuasan pelanggan tidak akan terlepas dari kinerja sebuah produk, apakah produk tersebut memiliki atribut yang bagus atau tidak, apakah produk tersebut sudah sesuai dengan kebutuhan pelanggan, hal itu akan berdampak dan berkorelasi pada kepuasan pelanggan yang diterima.

\section{Pengaruh Harga Terhadap Kepuasan Pelanggan.}

Berdasarkan hasil pengujian yang telah dilakukan didapatkan bahwa Harga berpengaruh terhadap kepuasan pelanggan dengan koefisien path sebesar 0,0987 tidak dapat diterima, dimana nilai $\mathrm{T}$-Statistic $=1,2155$ lebih kecil dari nilai $\mathrm{Z} \alpha=0,10(10 \%)=1,645$, maka non signifikan (positif), hal ini menunjukan harga yang dikenakan pada produk Billagio Skin Care tidak mempengaruhi kepuasan kepada pelanggannya, hal ini tidak sesuai dengan teori yang mengatakan kesesuaian harga yang dirasakan pelanggan semakin tinggi, maka akan menciptakan kepuasan pelanggan yang maksimal (Tjiptono, 2001) hal itu juga 2009). Dari analisis olah data diperoleh nilai factor loading pada indikator X.2.1 yaitu "keterjangkauan harga: nilainya paling rendah yaitu $\mathbf{0 , 5 4 6 1 6 2}$ yang artinya dalam hal keterjangkauan harga 
menurut pelanggan tertentu ada produk-produk tertentu yang harganya tinggi tidak sesuai dengan harapannya atau tidak sesuai dengan manfaat yang dia terima sehingga menimbulkan ketidakpuasan, disamping itu indikator lain pada variabel harga juga tidak mempunyai nilai yang cukup baik dalam menunjang variabel harga sebagai faktor yang bisa mempengaruhi kepuasan pelanggan. Hal itu bertentangan dengan penelitian Arlina Nurbaity dan Martin (2009) menyatakan bahwa harga berpengaruh positif terhadap kepuasan pelanggan.

Dimuka telah dijelaskan dalam membeli suatu produk pelanggan tidak hanya mempertimbangkan kualitasnya saja, tetapi juga memikirkan kelayakan harganya (Sweeney,et.al,2001). Harga merupakan salah satu penentu pemilihan produk yang nantinya akan berpengaruh terhadap kepuasan. Harga seringkali dikaitkan dengan kualitas, pelanggan cenderung untuk menggunakan harga sebagai indikator kualitas atau kepuasan potensial dari suatu produk. Bila suatu produk mengharuskan pelanggan mengeluarkan biaya yang lebih besar dibandingkan dengan manfaat yang diterima, maka yang terjadi adalah produk tersebut memiliki nilai negatif. Sebaliknya, apabila pelanggan mengganggap bahwa manfaat yang diterima lebih besar, maka yang terjadi adalah produk tersebut memiliki nilai yang positif.

Teori yang beranggapan bahwa suatu produk dengan harga yang mahal berarti mempunyai kualitas yang baik tidak berlaku pada produk kosmetik Billagio Skincare Clinic, harga tidak berpengaruh terhadap kepuasan pelanggan karena pelanggan untuk produk- produk jenis kosmetik dan perawatan rutin baik wajah atau kulit memiliki keterikatan dalam pemakaian rutin sehingga mau tidak mau pelanggan harus membeli produk tersebut secara berkala, yang penting bagi pelanggan produk tersebut sesuai harapan menghasilkan wajah yang cantik dan kulit yang bersih, sehingga harga tidak menjadi faktor utama bagi kepuasan pelanggan.

\section{Pengaruh Kualitas Layanan Terhadap Kepuasan Pelanggan.}

Berdasarkan hasil pengujian yang telah dilakukan didapatkan bahwa kualitas layanan berpengaruh (Positif) terhadap kepuasan pelanggan dengan koefisien path sebesar 0,5317 dapat diterima, dimana nilai T-Statistic $=6,975$ lebih besar dari nilai $\mathrm{Z} \alpha=0,10(10 \%)=1,645$, artinya Semakin meningkatnya kualitas layanan maka akan memberikan peningkatan terhadap kepuasan pelanggan, yang artinya layanan yang diberikan Billagio skin care clinic bisa diterima oleh pelanggan dengan baik.

Hasil analisis diperoleh bahwa, dari kelima dimensi (tangible, reliability, responsiveness, assurance dan empaty) pada kualitas layanan dilihat dari hasil gambar model konseptual PLS, nilai validitasnya yang paling tinggi adalah dimensi reliability yaitu dengan nilai path koefisien sebesar 3,354 dan nilai factor loading untuk masing-masing indikator X3.2.1 sebesar 66,252 dan X3.2.2 sebesar 49,419. Artinya realibility (keandalan) adalah kemampuan karyawan untuk memberikan layanan yang dapat diandalkan dan akurat dengan indikator Ketepatan waktu pelayanan kepada pelanggan dan Kecepatan dalam melayani pelanggan cukup ampuh sebagai alat layanan dalam memberikan kepuasan pada pelanggan Billagio Skin Care Clinic.

Hasil penelitian yang menyatakan bahwa adanya pengaruh kualitas layanan terhadap kepuasan pelanggan, memperkuat teori yang mengatakan Kualitas layanan adalah suatu bentuk penilaian pelanggan terhadap tingkat layanan yang diterima dengan tingkat yang diharapkan (Lupiyadi, 2001:81) dan sesuai dengan teori yang dikemukakan (Zeithaml, 
Parasuraman, dalam Ndaru Prasastono 2012). Kualitas pelayanan yang diterima pelanggan dinyatakan dalam ukuran besarnya kesesuaian antara harapan dan keinginan pelanggan dengan tingkat persepsi (Zeithaml, dalam Ndaru Prasastono 2012).

Kualitas pelayanan merupakan evaluasi pelanggan tentang kesempurnaan kinerja layanan. kualitas pelayanan mempunyai pengaruh positif terhadap kepuasan pelanggan. Jadi dengan peningkatan kualitas layanan yang diberikan kepada pelanggan maka kepuasan pelanggan akan tercipta. Lebih lanjut Ndaru Prasastono (2012) berpendapat ketika pelayanan yang diberikan mampu memenuhi pengharapan pelanggan, maka pelanggan yang bersangkutan akan merasa puas.

\section{Kesimpulan}

1. Dengan meningkatnya kualitas produk, maka semakin meningkat pula kepuasan pelanggan di Billagio skincare clinic.

2. Faktor Harga tidak mempengaruhi kepuasan pelanggan Billagio Skincare Clinic.

3. Kualitas layanan yang ditingkatkan, berdampak pada meningkatnya kepuasan pelanggan di Billagio skin care clinic.

\section{Saran}

1. Bagi pengusaha Billagio skin care clinic seharusnya memperhatikan harga sesuai dengan harapan dan sesuai dengan manfaat yang diharapkan agar memenuhi kepuasan pelanggan.

2. Bagi pengusaha Billagio skin care clinic hendaknya lebih meningkatkan kualitas produk yang inovatif dan kualitas pelayanan da

lam hal perawatan agar konsumen puas dan loyal.

3. Bagi Peneliti berikutnya, penelitian ini bisa menjadi bahan untuk penelitian yang lebih kompleks lagi sampai dengan loyalitas pelanggan.

\section{DAFTAR PUSTAKA}

Alma, Buchari, 2000, Manajemen Pemasaran dan Pemasaran Jasa, Penerbit Alfabeta, Bandung.

Darsono, L. Indahwati, 2010, Hubungan Perceived Service Quality dan Loyalitas; Peran Trust dan Saticfaction Sebagai Mediator, Jurnal bisnis Perspektif, Vol 2 No.1. hal 4357

Engel, James F ; Roger D Blackwell : Paul W Minniard, 1995, Consumer Behavior, The Dryden Press, Orlando, Eight Edition, International Edition.

Fajar Laksana, 2008, Manajemen Pemasaran, Graha Ilmu, Yogyakarta. 
Ferdinand, Agusty, 2002, Structural Equation Modelling Dalam Penelitian Manajemen, Edisi 2, Penerbit : BP UNDIP, Semarang.

Ghozali, Imam, 2011, Structural Equation Modeling Metode Alternatif dengan Partial Least Square PLS, Edisi 3, Badan Penerbit UNDIP, Semarang.

Hasan, Ali, 2006, Marketing, Media Utama, Yogyakarta.

Kotler, Philip and Amstrong, Gary 2008, Prinsip - Prinsip Pemasaran, Jilid 1, Edisi Kedelapan, Alih Bahasa oleh Damas Sihombing, MBA., Penerbit Erlangga, Jakarta.

Kotler, Philip and Amstrong, Gary, 2004. Dasar - Dasar Pemasaran, Jilid 2, Edisi ke-9, Indeks, Jakarta.

Kotler, Philip, 1997, Manajemen Pemasaran (Analisis, Perencanaan, Implementasi \& Kontrol), Prenhalindo, Jakarta.

Malhota, N.K., 2005, Marketing Research (4thed), New Jersey : Pearson Edition. Marhayanie \& sihite, Eka Larasati, 2008, Pengaruh Atribut Produk Terhadap Green

Product Cosmetic (Study Kasus Pada Putri Ayu Marta Tilaar Sun Plaza Medan). Jurnal Manajemen \& Bisnis, No. 1, Hal 10-17.

Mital, Vikas, William T. Ross and Patrick M Baldasare, 1998, "The Asymetric Impact of Negative and Positive Attribute Level Performance on Overall Satisfaction and Repurchase Intentions", Journal of Marketing,, Vol. 62. P.33-47.

Musanto, Trisno, 2004, Jurnal Faktor - Faktor Kepuasan Pelanggan dan Loyalitas,

Fakultas Ekonomi Universitas Katolik Widya Mandala, Surabaya.

Mulyono \& Yoestini, Nugraheni, Kamal, 2003, Analisis Pengaruh Kualitas Produk \& kualitas Layanan Terhadap Kepuasan Konsumen (Studi Kasus Pada Perumahan Puri Mediterania Semarang). Jurnal Ekonomi dan Bisnis, No.3, Hal 43-57.

Nurbaity, Arlina dan Marin, Pengaruh Harga (Prince) dan Kualitas Pelayanan (Service Quality) terhadap Kepuasan Pasien Rawat Inap di RSU Deli Medan, Jurnal Manajemen Bisnis Vol 2, No. 1, Jan 2009, 21-24, Universitas Sumatera Utara, Medan.

Prasastono, Ndaru, dan Pradapa, Sri Yulianto Fajar, 2012, Kualitas Produk dan Kualitas Pelayanan terhadap Kepuasan Konsumen Kentucky Fried Chicken Semarang Candi, Jurnal Dinamika Kepariwisataan Vol. I, No. 2 Oktober 2012, Universitas Sikubank, Semarang.

Sideng,Nurlaela, 2013, Pengaruh Kualitas Pelayanan Terhadap Kepuasan Konsumen Pada PT.Putra Sulawesi Sejati Perkasa Gorontalo, Jurnal Ekonomi dan Bisnis, No.4, Hal 17-24.

Samuel, Hatane, 2005, "Pengaruh Kepuasaan Konsumen Terhadap Kesetiaan Merek". Studi Kasus Restoran The prime \& Ribs Surabaya". Jurnal Manajemen dan Kewirausahaan Vol.7, No.1.

Sukmawati, Kartik, 2011, "Pengaruh Kualitas Layanan, Harga, dan Kepuasan Pelanggan Terhadap Loyalitas Pelanggan Jasa Transportasi Kereta Api Eksekutif, Jurnal Manajemen FE - Ing Gunadarma, Jakarta.

Suwarni dan Mayasari, Septina Dwi, 2011, Pengaruh Kualitas Produk dan Harga Terhadap Loyalitas melalui Kepuasan Konsumen, Jurnal Ekonomi Bisnis, Th 16, 
EkoNiKa | Vol. 1, No. 1, April 2016:78-90

No. 1 Maret 2011, FE Universitas Negeri Malang, Malang.

Swasta, Basu, 1991, Manajemen Pemassaran, Analisa Perilaku Konsumen, Edisi Pertama, Cetakan Ketiga, Yogyakarta.

Tjiptono, Fandy, 1997, Strategi Pemasaran, Edisi Kedua, Penerbit Andi Offset, Jakarta. , 2000, Manajemen Jasa, Edisi Pertama, Penerbit Andi Offset, Jakarta. 2002, Strategi Pemasaran, Edisi Kedua, Penerbit AndiOffset, Jakarta.

Zeithanil, Valarie A., A. Parasuraman and Berry L. Leonard, 2000, Delivering Quality Service : Balacing Costoer Perception Expectation, Newyork. 